\title{
Traces of contempt and traces of self-esteem
}

\section{Deconstructing our toxic colonial legacy}

\author{
Dalila Mahdjoub, translated from French by \\ Shirley Lambert
}

As the Senegalese scholar, musician and writer Felwine Sarr has written: 'Colonization has left substantial traces on self-esteem... There is a plethora of stigma we have to work through to re-articulate a favourable and fertile presence in the world and to retake ownership of ourselves' (Sarr 2016, 89). Sarr's words resonate well beyond the borders of Africa. These words echoed a diffuse and devastating feeling deep inside me. I feel a sense of urgency to deconstruct these stratified traces of internalized contempt in order to neutralize them. These 'traces of contempt' - the residue of an alleged superiority of one human group over another human group - could be similar to the dust of the nano-racism described by Achille Mbembe (2016). This 'narcotic form of the prejudice of color, which is expressed in seemingly innocuous everyday gestures, in the course of a nothing, an apparently unconscious remark, a quip, an allusion, an insinuation, a slip, a joke, an innuendo'. Or as Raoul Peck describes it: "Light" racism is also racism. It hurts just as much. Especially when it persists innocently and builds up' (Peck 2020, 25).

It is from this uncertain and vague place in some region of my head where these little traces of contempt accumulate that the matrix of my work as an artist is formed. A place where images, stories - sound or video - of my loved ones mingle, and archives that do not directly affect me, the whole constituting my bitter-deposit to be deconstructed. My 'pharmacy' of Fanon, Baldwin, Mbembe, and Sarr offers me tools-concepts to deconstruct and build my archives-works (Phay 2016). There is for me something in all of this on the order of vomiting (Baldwin 1975), as if to purge myself of filth, to free myself of it and to reconcile with me and mine. I place - here-four fragments of an unfinished/in process inventory, the off-screen of my past or future creations, overseen by my portmanteau of words (Sarr 2016). It is from a few snippets of family stories that I will try to understand the roots of a cumbersome and instinctual violence that overwhelmed my father despite himself and that I found as something normal in the majority of immigrant men in our neighbourhood. I did not want to resign myself to this idea, which I sometimes heard from my mother's lips, that the French were more civilized than us and thus had the monopoly on gentleness, kindness, and good manners. My intention rather is to pull the threads back to the roots of this violence, to 


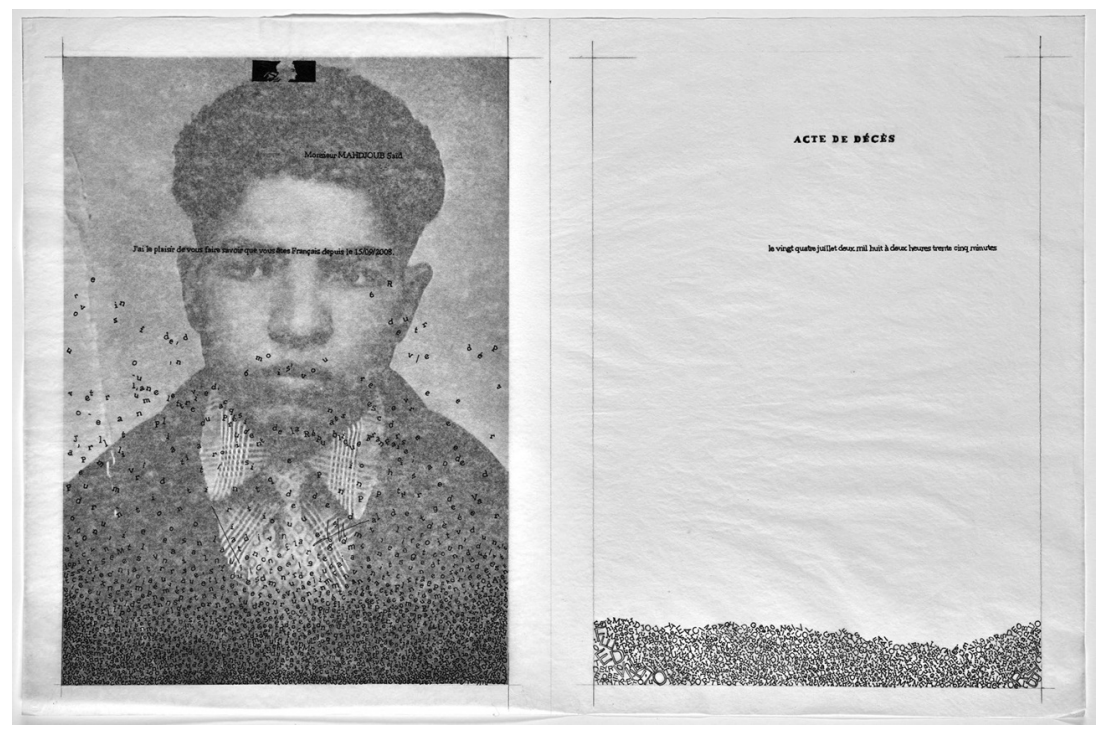

Figure 10.I I have the pleasure... Drawing in black ink and soft pencil $0.05 \mathrm{~mm}$ on tissue paper, photograph. Papiers de soi(e) series. Format $50 \mathrm{x}$ $32.9 \mathrm{~cm}, 2017$.

what made my parents come to this country where they were neither awaited nor wanted. Thus, the method put to use here is (auto-)biographical and multi-vocal, presenting the testimonies of different family members whose experiences bear witness to everyday racism — past and present - through their own wordings and framings (Figure 10.1).

\section{Go To Ben-Bella}

\section{Said Mahdjoub}

This passage is taken from a series of interviews with my father between February and July 2003 when he agreed to be filmed. A small DV (digital video) camera, placed on a stand, filmed while my father, who was in his appointed seat in the corner of the black leather couch, in the high-rise apartment at Champs-montant, told the stories of his work between France and Algeria with precision and fluidity. I was working then on the Sonacotra project. ${ }^{1}$ The specific time we chose corresponded to his return to France at the end of 1964. His first stay for work began in the fall of 1956, after his father and older brother had forced him to leave the Koranic school to guard the sheep. He was then about seventeen. At the end of 1962, after Algeria's independence, he 'returned definitively'. Very quickly, driven by poverty, he made arrangements for a new return to France at the end of 1964. He found himself in a room in the Foyer Sonacotra in Sochaux, specifying, 'I lived on 
the eighth floor'. At that time, the doors to work were closing. This moment started with a dream. The dream of a voice, on a Monday morning, while he was still asleep.

One Sunday afternoon I was sitting with some friends from the Foyer Sonacotra. And I told them, as we Arabs say, 'Someone who does good and who has not done evil, the good God he has done something good for him! Me, I did nothing wrong and the good God he has done nothing but wrong! I don't know why!' And I was pissed off. And I said to them, 'My word, if tomorrow "I'm not hiring", the day after tomorrow I won't spend the night here!' And that was true! And where will you go? I was going to go to one of my brothers, Said, in Port-de-Bouc. And I didn't know the region, I thought I would find work there, but there was none. Luckily I didn't go. I had sworn, and I was going to go. I had just enough money. I was counting on the room that I was going to give back and get back my deposit. And I was going to go with the few pennies I had left. I wanted to go to Said and perhaps I would find some work there? The good God had decided that my fate was here. We went to sleep there that night. I in my room! Very early Monday morning, the others hadn't got up yet for work, and someone came to see me, someone came to me, I didn't see him, I was still asleep, someone was with me and was talking to me, 'Get up and go to work!' I told him, 'No! For me there is no work!' He said to me, 'Yes! There's work at Leroy's! There's none at the other place!' Like that! I said, 'No, Leroy-he made me work four days and after that he told me there wasn't any!' He told me, 'I told you Leroy's! There's none at the other place!' Twice! I was startled, I woke up, and I realized I was alone! No one! All alone!

I went back on foot to Sochaux ... I arrived at the roundabout - at that time there was a store there called Suma, a department store instead of Daguet, a store/supermarket - it didn't close at noon. I went in and bought a baguette and a piece of Gervais cheese and a bottle of water ... I told myself, I'll eat and go back out this afternoon and make another round of the offices in this neighbourhood ... If I find work, good; if I don't find any, I'll go see Mr. Mafa and ask for my deposit, and I'll go join my brother the same day! I came home, my aunt's son asked me if I had been hired ... I told him, 'No, nothing at all!' He said, 'So will you leave this evening?' Wait, I still have this afternoon, I'll make another round, and if there's nothing, I swear I won't spend another night here! And it was true. And first of all, leave me alone! I was angry. Several residents were there and were eating a marga (stew) with meat, they invited me to come and eat with them. I told them no! I'm not eating. They asked me why ... I told them God had given me cheese and some bread. I would eat the cheese and bread that were mine! You, He has given you work! Me, in spite of my hands, there is no work! And so, I am eating my 
bread and my cheese! I'm not eating with you! They insisted, I said NO! I put down my cheese and bread and ate, then I drank a coffee.

And they left to go to work and me, I went to Sochaux. I had already passed by Héricourt, I went to an office ... I was still on the sidewalkthat day, I was no longer just looking to get hired, I intended to get angry! I was angry. I didn't even realize what I was doing - I got to this office ... He said, 'Leave!' sweeping the air with a wave of the back of his right hand. Heck no, I'm coming in! I was in, and I was angry! When I was inside, he said, 'Why did you come in, I told you to leave!' I said to him, 'Why, is it forbidden to walk on the sidewalk?' He said, 'Algerians like you", they come here to ask for work!' Well, no, I came to have a walk! And then you, you tell me to leave! You don't have 'the' right! And I didn't come to ask you for a job! I came for a walk! And I have the right to walk on the sidewalk! It's for the town, not for you! I made quite a scene. He said to me, 'Go on, leave.' I left there and rubbed it in by going to the next office, 'it makes no difference'. I wasn't looking for a job! At that moment I was just looking to shout my head off.

At any rate, they didn't want to give me a job. Because in the last few days, when I went to see them, they told me 'Go to Ben-Bella!' And yes, today, I had only my anger to pour out on them, and I would go from there! I wouldn't be working for them! I didn't want to anymore! That day my anger got in front of my steps! It preceded me! Rage was overwhelming me! I got angry in all three offices there ... And I came back to Sochaux, I arrived at the brasserie - there was no autoroute at that time, the route for Belfort was the one that passed by Vieux-Charmont-I had heard that there was a boss called Sodrac, those who wanted to work, he would hire them. I told myself, I'm going to go round by his place to see if he wants to give me a job ... And if he doesn't hire me, it's the last one. I'll come home to put my stuff away, and I'll leave. But I wasn't done! I got to the roundabout, a policeman was standing next to me, directing traffic, it was a quarter to two ... And the lady who worked as secretary in the Labor Office came by with her Quatrelle ... I saw her! She put her head out of the window like this and smiled ... She told me, 'Come!' The policeman standing next to me cheated me, he went to her! Now that the police officer had gone to her, I lowered my head and passed the crosswalk in front of her, I didn't look at her at all and took the sidewalk towards Vieux-Charmont!

I had walked some two or three hundred meters ... There was a red light for her, the light turned green, she passed in front of me, she stopped her Quatrelle, she was on the sidewalk facing me and called me, like the voice in the morning! 'Mahdjoub Said! Mahdjoub Said!' I turned to her, she beckoned to me and said, 'Come quickly, I have to go to work.' I crossed the road and joined her. She said to me, 'I have taken a lot of trouble for you.' I said, 'How so?' She said, 'Mr. Fester, there are a lot of people who come to see him, he gives them papers, and they choose a 
job, and you, he never gave you a paper! And, well, I found you a job! My word, I looked everywhere, there was nothing, there was only something at Leroy's! There was not another place!.' It looked like it was she who had spoken to me that same morning! One could say it was her! How was this possible? The same words? She told me, 'It's only for four days, but if you take my advice, go work!' I told her, for just a day, I would work! Because I had sworn to! So for four days ... At that moment, she was alone in her Quatrelle, I hesitated to ask her, could I get in with you ... No! No, no, it was too much for me to ask! I couldn't! I couldn't ask her to let me get in her car! I let her leave with her Quatrelle. Neither did she suggest that I get in with her, nor did I ask her to let me get in! For me the chief thing was that she had found me a job! The same day!

So she, she left in her Quatrelle. And there were coaches, they came from Belfort, passed through Vieux-Charmont and stopped in front of the railway station of Montbéliard. Their yard was there. And every halfhour there were two that left, two that arrived from Belfort, all day long. She drove off to get to work on time, and I walked past the Prado cinema in Sochaux, the bus stop was there. I arrived at the bus station, I swear I didn't wait a second! I got to the shelter level, there were people waiting, I stopped and the bus came inside, brushing me lightly, I didn't have to wait at all! It arrived at that very time. It stopped, I got on first. At that time you paid 50 centimes, I paid and got on. It stopped in front of the railway station. I got off and took the Montbéliard road and went in the direction of Sainte-Suzanne to the Labor Office. When I arrived, I found the room packed! I couldn't even get to the door. I said, 'Leave me be, I want to get through the door.' You know Arabs! And the people were testy, they didn't have jobs, there was no work! There was one who said to me, 'What do you mean? You arrive after the others and you want to go through the door?' I told him, 'I have an appointment with Modeva [the labor recruiter].' 'No, no, no, Modeva doesn't give appointments.' I told him, 'To me, yes!' He replied, 'No!' Nonetheless, the other people told him, they told him, 'Let him by, he's going through the door.' He said to me, 'If you are going to knock on the door, he's going to insult us!' I told him, 'In any case, our faces are what he's insulting. They have always insulted us! As if we had any value! Nor would we have had to come here! Nor would they insult us! Let me go through the door!' He got in my way, I grabbed him, I pushed him out of my way, I tossed him aside, he fell on the others! They said, 'You want to mess with all of us or what!' There was one of them who walked over and said to them, 'Let him through the door!' I told him, I'm going up to the door, whether we have to fight or not! The door, I'm going to it! This isn't your affair! He said to me, 'Now he's going to insult us!' I told him, 'That's not your problem!'

I went up to the door and began knocking softly. And this Fester, he was a bad one! He answered from inside, 'There's already someone here with me! Who's knocking on that door! Leave the door alone!' And so, I 
was pissed! I gave the door a huge kick! Like a crazy person, that day! I told him, 'Well, I'm breaking that door! How unhappy you are! How unhappy you all are! So, yeah, I'm breaking this door!' I found myself deciding, like him! I kicked the door! One of them said, 'Didn't you hear that?' I said, 'You shut up, Arab!' I told him, 'Me, I'm breaking this door!' Nothing could have stopped me that day. And that worked! That worked! And then this lady came, she opened the door, she said to me, 'Ah! Mr. Mahdjoub, come in!' He said to her, 'There is already someone in front of me!' She said to him, 'No, no, no, it is I who told Mr. Mahdjoub to come!' Everything I had done was ok. It didn't matter. When it has to happen, it happens. I went in, she closed the door behind me.

In 1977, Lionel Stoleru, then Secretary of State for Labor, said, 'We don't kick anyone out, but we don't leave the door wide open like before', defending his return assistance measure, the so-called million Stoleru. ${ }^{2}$

In 1981, I remember, I was 12, the bus for the Peugeot workers had just stopped at the bottom of our apartment building, I was doing my homework in the small room next to my sisters' and my bedroom. My father came in and asked my mother to come into the kitchen. His tone-usually authoritarian - seemed suddenly more serious, 'Habou y taichouna!' (They want to throw us out!) 'Over there we have nothing; we don't have a house!' Later on, my father told me, 'The bosses at Peugeot called in the immigrants and especially the Algerians to force them to go back home.' And yet, poet and Kabyle singer Sliman Azem would sing, 'Neither has he gone away, nor has he stayed, neither has he stayed, nor has he gone away.'

The double injunction, recurring and humiliating, to 'go home' and that of having to justify our presence, weakens our legitimacy to be here as descendants of France's colonial adventure. 'Where do you come from? Yes, but before, where were you born? Ah! But before then, you, your family, where did it come from?' (Taubira 2018, 13). Christiane Taubira recalls these questions, seemingly so innocuous and devoid of malice, but whose repetition throughout a lifetime freezes us in a status of eternal 'alien or immigrant of an umpteenth generation' $(2018,13)$. The order to have to justify our presence is fruitless. It only adds to the lack of consideration, projecting a demeaning self-image onto the targeted people. As Frantz Fanon aptly reminds us, 'If there is a pointless approach, it is certainly one which consists, for an oppressed person, in speaking to the "heart" of his oppressors' (2014a, 524).

In addition, this order calls for restorative work on ourselves. 'To leave the shame, to reverse the stigma, to reverse this shame that weighs upon our origins. We are forced to do difficult work!' says Serge Romana (2019). In my father's account, violence became a means of 'rehabilitating himself in his own eyes' (Fanon 2014b, 496). When he explained to me - with aplomb, 'I took to deciding, like him!' he was doing neither more nor less than what 


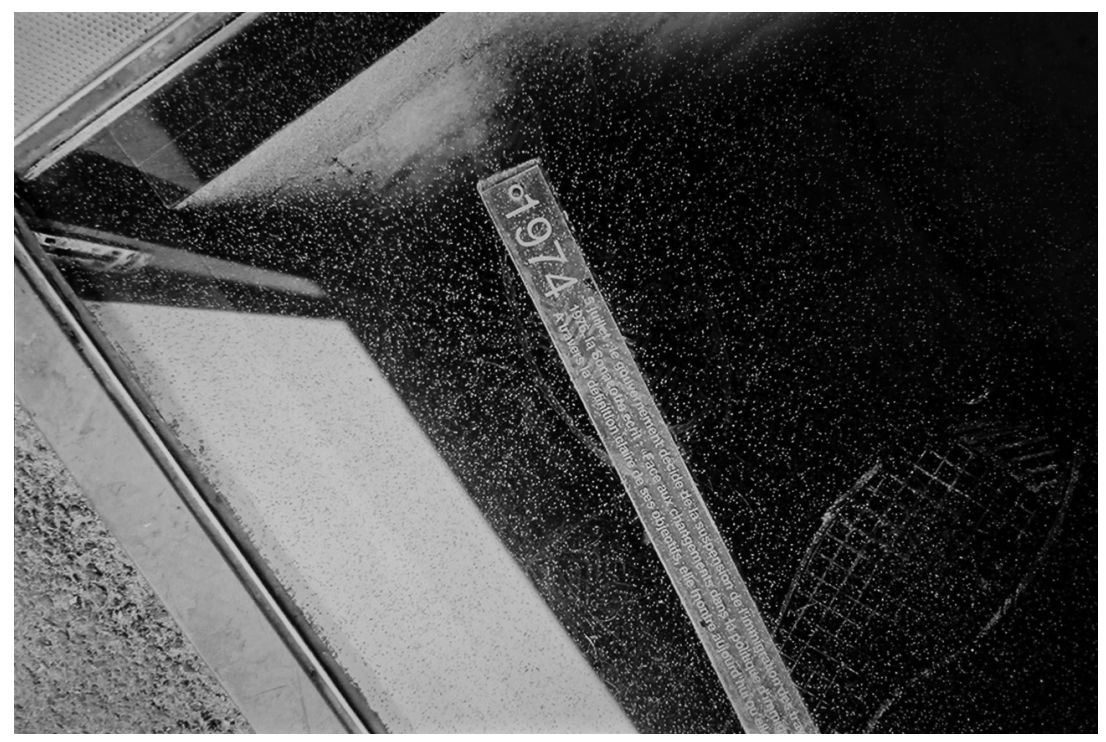

Figure 10.2 From One Threshold to Another. Installation on the threshold of the Adoma social housing (formerly Sonacotra), two bedroom doors from the first Sonacotra home Le Parc in Argenteuil, silkscreen print. Dimensions of the space, I × I × 2.10 metres. Marseille, 2007.

Frantz Fanon has described: 'At the level of the individual, violence detoxifies. From the colonized it gets rid of his inferiority complex, of his contemplative or hopeless attitudes ... Violence raises the people to the loftiness of the leader' (Fanon 2014b, 496). A path of reparation to get out of 'self loathing' that is too often reflected in ambivalent relationships, mixed with mistrust between Algerians from here and from over there: 'Blédards', 'Bnat frança', 'Ouled frança', 'The villas of the immigrants'. Symptoms of this iniquitous and persistent divide between Europe/West and Africa. What connects a master to his slave is even more tragic than what separates them? (Baldwin 1975) (Figure 10.2).

\section{The executive}

\section{Habiba Mahdjoub}

Racism is based squarely on a question of power. Racism begins at some point when you have the power to define me. Such a power that I will not escape your definition. 
This audio recording was produced in August 2020. At my request, my sister Habiba recalled this moment - which she had told me about several years before - a moment of suspended silence.

It concerns my training as part of my position as a staff representative. The training took place over five days in Belfort, in a hotel conference room. We were five CFE-CGC [French Confederation of ManagementGeneral Confederation of Executives] representatives, executive representatives from the company Safran Landing Systems in Molsheim. We were there with other executives from other companies, overall, we were a bit less than 20, and there were three or four companies represented in the room. The trainer came from Lyon, five days of training, each one a full day. The training went very well, but from the start of the meeting I noticed a small young woman, fairly young, pregnant, who was sitting across from me. The tables were laid out in a $U$ shape and the trainer had his table in the middle. And so, facing me, there was this tiny young woman, very nice, and I felt her gaze from the first day of training, but a rather insistent look, even embarrassing, because at the beginning I met her gaze several times, it wasn't too annoying, but after a while, I felt that it was non-stop. And I found that a little weird.

The first day we had a little coffee break in the middle of the morning and the young woman came up to me while I was helping myself to some coffee, she actually came to apologize. She introduced herself and then told me, 'I just want to apologize because you certainly must have felt my rather insistent gaze on you.' Then she made a small remark about my hair, with regard to the length and colour of my hair that had impressed her - but not that - what had especially impressed her was the fact that 'a-person-like-me' called Habiba Mahdjoub, with her lightly tan skin could be the personnel representative, could be an executive in an Alsatian company, especially Alsatian. Because she had never seen that before. And she, she came from an Alsatian company located more to the north of Alsace and well to the north of the Bas-Rhin. And in fact, they didn't have a 'person-like-me' on the staff of the company or likewise on the management staff. She told me, 'I'm very surprised to see that a 'person-of-your-origin' can represent an Alsatian company, management and chosen, this is unheard of in an Alsatian company.' Afterwards, she made a slight comparison with her company, telling me that there was not a 'person-of-foreign-origin' like me. And so to see people with an executive position and, in addition, representing the staff, that for her was 'Wow!' She immediately apologized again, saying, 'please don't take this the wrong way! I have no preconceptions about "people-of-foreignorigins". Quite the contrary! It's pretty good that we have "people-ofdifferent-nationalities" or of "different-origins".' She said, 'It's what is lacking in our Alsatian companies.' 
It was in this little fleeting moment of astonishment, which was expressed between my sister and this young woman by way of a simple look that was unusually insistent, invested with good will, a look that caused my sister embarrassment and discomfort, a look that led the young woman to feel obliged to apologize, her excuses mixed with well-meaning flattery - it is in this suspended time, where the presumed executive takes shape and implodes here - in which you, the 'person-of-foreign-origin', you are unconsciously predictable. There follows the flattery, to which watchfulness encourages you not to consent, if you want to avoid being locked into the figure of 'you-arenot-like-the-others', or even the phantom-figure 'you evolved people' with its dangerous pitfall of exemplariness, success, and meritocracy that separates me from my peers and therefore from myself.

I have the memory of my father's words, 'Work in school to have a trade, so that no one can walk over you.' In his way, he was telling us what James Baldwin wrote to his nephew,

You were born into a society which spelled out with brutal clarity, and in as many ways as possible, that you were a worthless human being. You are not expected to aspire to excellence: you were expected to make peace with mediocrity'.

(Baldwin 2018, 29)

Christiane Taubira adds,

To this speculation on mediocrity, that of consenting to paternalism as befits unfinished beings, of corresponding to clichés in order to arouse compassion, or even of giving in to assimilation, alienation being very close with its inevitable procession of frustrations and disabilities that Frantz Fanon described better than ever'.

(Taubira 2018, 13)

\section{Rage}

\section{Djamel Mahdjoub}

Being under-estimated, not being considered, is the reason for rage. In a certain way it is even more painful, because it is much more common, much more mundane, it is even more dangerous than utterly brutal things like lynching or massacre. Inevitably, we want to be considered at any cost!

(Baldwin 1975)

The following dialogue comes from a conversation between my brother and me, a moment when we spoke of everything and nothing, where the words 
were free and could escape as soon as they were spoken. It was at Fos-surMer at our mother's house in August 2020, where I, as I often did, needed my cell phone to record the accuracy of my brother's crude words, steeped in crystallized anger. His words, as if chanted, speak of saturation from the accumulation of these traces of an ambient and mundane contempt. Faced with this contempt- - however residual it might be and from force of habiteach one of us uses self-esteem defence strategies. Our discussions were part of this work on our self-esteem. This scene took place in 2008 in the context of a welding training programme at the AFPA (National Agency for the Professional Training of Adults) in Belfort.

The 'fat guy' every time he said - there was a 'black' with us - you know, a guy my age, he always called him 'the nigger', 'Oh, the nigger!' The 'black' said nothing. You know, he was a 'little-meskin [poor] guy.' I said to him, 'Why are you letting him do it! Slap him in the face!' He replied, 'It's not important. It's nothing.'

'Don't let him talk to you like that!'

He said to me, 'It's nothing. It's not mean.'

Ok! If he doesn't want to defend himself, I'm not the one who is going to defend him! Me, I don't give a damn!

There was one morning, we were having coffee. We started at eight o'clock and then we had the dining hall, we poured the coffee into a machine, and then it happened like this, I swear! The fat guy opened the door and walked in like someone who thinks they are awesome! And then he came in like that ... I don't know what that was about! Yeah, he was sitting in front of me, like that! He said to me, 'Anyway, "people-like-you", how often do you change your residence cards?' Then I said, 'What?' I said to myself, 'I misunderstood that! What do you mean! "People-like-you"?'

He said to me, 'Yeah, well, you! Your residence cards, how long do you have them?' I looked at him and said, 'Are you stupid or are you doing it on purpose!' I added, 'In my opinion, you're stupid!'

He looked at me and said, 'Pardon me?'

I told him, 'Shut up! Stop talking already! And what's more, stop talking to me! Don't talk to me!' Then he began to play the game, you see ... I got up, I blew a fuse, I swear! I got up and said to him, 'Now you are going to shut your trap, you know what! And you're going to kneel down in front of the door there! Get down on your knees right now and apologize. Get down on your knees!'

Then he got up like that and said to me, 'Apologize for what?' 
There were only French people! And the 'whites,' they said to me, 'Oh Djamel, it's ok.'

I told them, 'You, you shut up, I'm talking to him now!' He was looking at me like this, then he said to me ... he began to 'uh, uh,' like the kids, you know when you yell at them! And then the 'whites', they were saying to me, 'Djamel, it's ok.' You know, I was really aggravated! I told him, 'Now, you know what, either you get down on your knees, or I'll bash your head against the wall! Now, get on your knees! It's the last time I'm telling you!' He did it. He got down on his knees! 'Now, you know what, you're going to stay on your knees! I'm going to drink my coffee! And then if you're good, you get up and we'll see later!' He stayed on his knees! No more noise in the room! I swear, nothing! I sat down, I was like that. (Mimicking his hands trembling with anger.) I drank my coffee like that, then I looked at him. And you know, he was gasping for air! Then I looked at him and no mercy! I looked at him like that. I left him at least five, ten minutes on his knees like that, like a dog! And then I looked at him like that and said, 'You know what, now you're going to get up! I'm never going to see you again. In the workshop, if you see me in front of you, fiit, you change direction! You understand?'

He replied, 'Yeah, yeah, ok!'

I said to him, 'From now on, when you see me in the room, you don't come in anymore! Go on, beat it!' He didn't speak again. Never again in his life! 'Ah, that's the way you should talk now!'

ME: But don't you think that this attitude, mind you, risks provoking even more hatred?

DJAMEL: It will be justified! Look, you speak, you take the consequences! How you talk! How do you say 'the nigger'! How do you say that! You see that in telling us nothing, you take us for 'less-than-nothing'! So there! At some point, stop! Stop! Stop! Me, I've always respected you! Respect me! Don't love yourself! You are racist! I don't give a fuck! But don't come looking for me! Where do you come from that you believe that people, they have residence cards! Where are you from? Are you stupid or what! No, but really! Where are you from! Damn, I was born here! I still have to prove myself! I have to do more things than you do! Behind the two faces acceptable to the Republic, that of 'You-aren't-likethe-others' or that of the 'unfinished being', looms the face-more threatening, deportable by The Republic, which will degenerate to just one possible outcome - the face of the young savage, the thug, the delinquent, the barbarian, the Islamist, even the terrorist.

The violence that Djamel expresses here-similar to that of my father, almost instinctual - became a means that 'detoxifies. It rids (the colonized person) the individual — of his inferiority complex' (Fanon 2014b, 496). 


\section{Vomiting the face of 'you-are-not-like-the-others'}

\section{Small shift of the bottle on the small yellow notebook}

Traces of contempt are also found in images (Figure 10.3). One of these traces is nested - here - in the gesture of the illustrators, in the replacement of an object (the bottle) by another (the small yellow notebook). It was by chance, about twenty years ago, that I brought together these two nearly identical images (in the centre). One is a black and white photograph, the other is an illustration from the autobiographical novel by the FrancoAlgerian author Azouz Begag. For a long time, I asked myself what thought process would have led illustrators to refer to this representation of a child from a propaganda work, Algeria: Birth of a Thousand Villages (Algerie 1960). This publication extols the merits of the regroupment camps in the middle of the Algerian war. 'Thanks to the regrouping, schooling is developing ... with makeshift resources ... which are improving each day. Even in the provisional regroupment camps, in French, in Arabic, ... children are being educated.'

At the end of November 2018, I got in touch with the illustrator. To my question, 'Why did you choose this book as a source of inspiration?' she replied, 'the publisher gave us the book from which we took the picture', and, 'we needed a little Arab'. Here the captions on the source image that run the length of these fantasized representations only remind us of what - a few

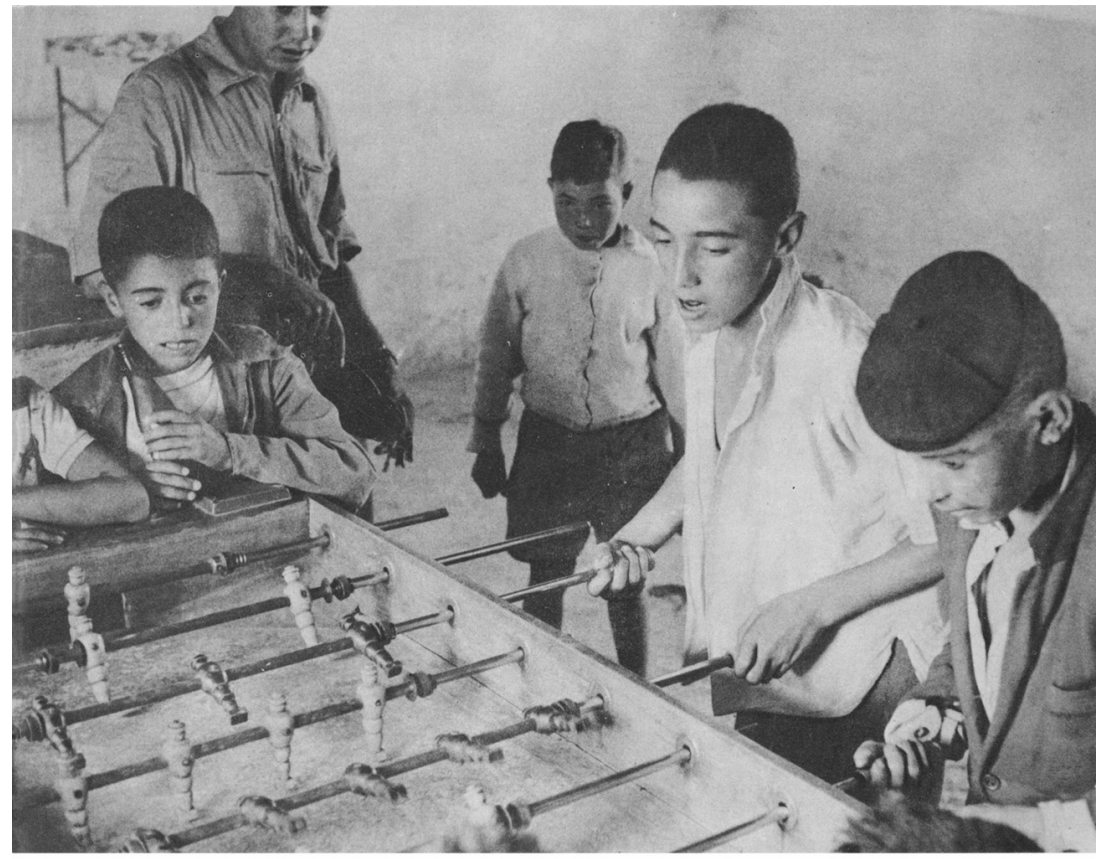

(a) 


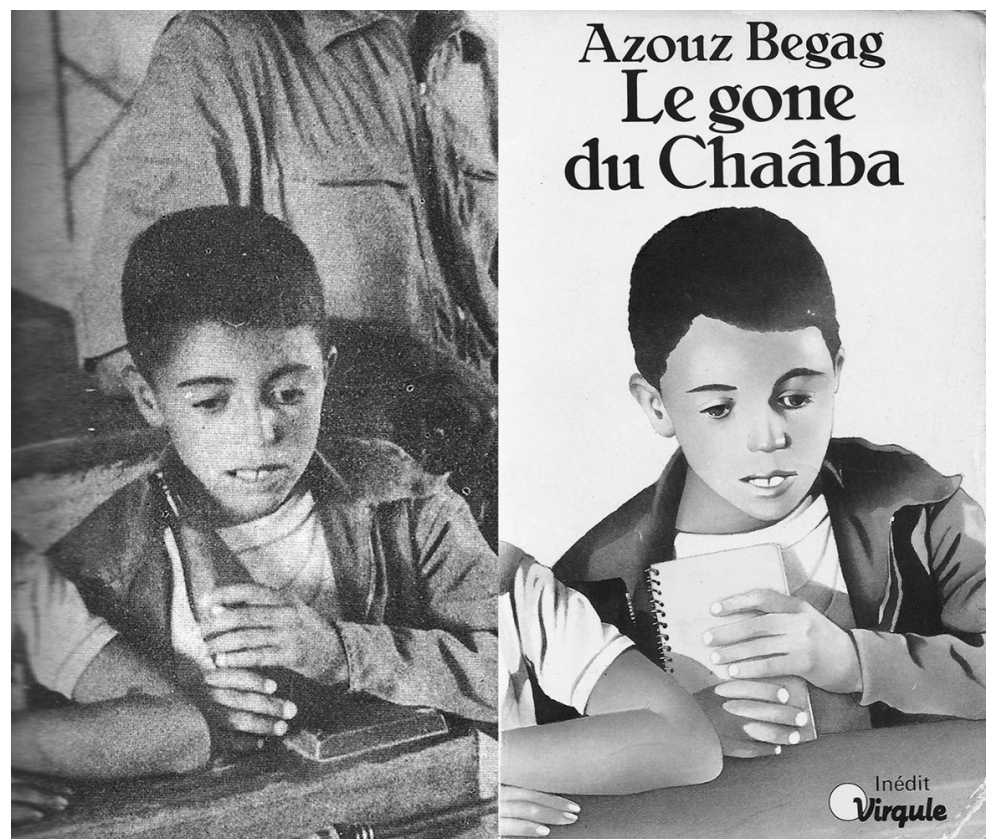

(b)

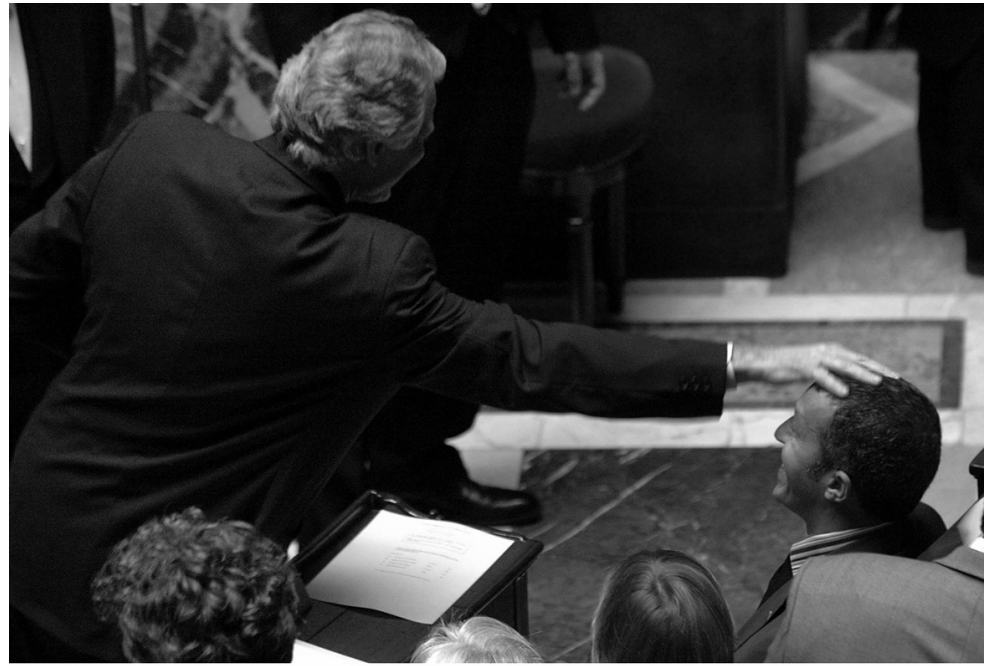

(c)

Figure 10.3 Naissance de mille villages, Algerie. Imprimerie Baconnier, December 1960. Illustration de couverture Monique Rozier-Gaudriault et Jacques Rozier, Le gône du Chaâba, Azouz Begag, Éditions du Seuil, January 1986. En juin, à l'Assemblée Nationale, Dominique de Villepin chahute avec Azouz Begag, ministre délégué à la promotion de l'égalité des chances, photography by Mehdi Fedouach, Le Monde, 8 November 2005, 3 @ AFP. 
variété. Par exemple, l'étonnement, la surprise se marquent en général par le relèvement des sourcilset l'ouverture de la bouche. Mais certains peuples (Esquimaux, Indiensdu Brésil) accompagnent ces jeux de physionomie par une claque sur les hanches. Les Aïnos de Yeso se donnent une légère tape sur le nez ou la bouche, tandis que les Tibétains pincent leur joue. Les nègres Bantous portent leur main devant la bouche; les Australiens, les Nè-

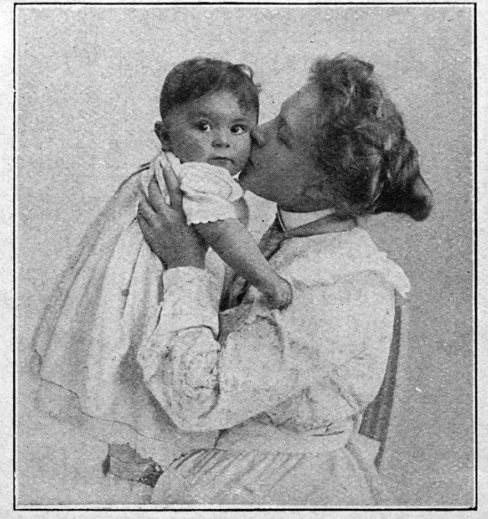

EuROPÉENNE EMBRASSANT SON ENFANT. - Nul geste ne nous paraît plus naturel, plus instinctif que celui-là. Pourtant il existe bon nombre de peuples qui lignorent totalement. (Cl. Boissonnas et Taponier.) gres occidentaux projettent les lèvres en avant comme pour souffler, etc. Les Tibétains saluent l'étranger en tirant la langue. Les Maoris de NouvelleZélande se disent bonjour en se frottant le nez. Tandis que dans la plus grande partie de l'Europe on exprime la négative par un hochement de tête horizontal, et l'affirmative par un hochement vertical, les Grecs font le contraire. Les Français sifflent un acteur pour manifester leur mécontentement, les Améri-

(a)

variété. $\mathrm{Par}$ exemple, l'étonnement, la surprise se marquent en général par le relèvement des sourcils et l'ouverture de la bouche. Mais certains peuples (Esquimaux, Indiens du Brésil) accompagnent ces jeux de physionomie par une claque sur les hanches. Les Aïnos de Yeso se donnent une légère tape sur le nez ou la bouche, tandis que les Tibétains pincent leur joue. Les nègres Bantous portent leur main devant la bouche; les Australiens, les Nè-

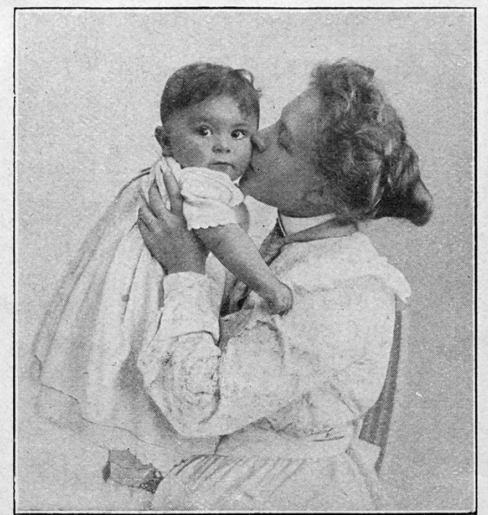

gres occidentaux projettent les lèvres en avant comme pour souffler, etc. Les Tibétains saluent l'étranger en tirant la langue. Les Maoris de NouvelleZélande se disent bonjour en se frottant le nez. Tandis que dans la plus grande partie de l'Europe on exprime la négative par un hochement de tête horizontal, et l'affirmative par un hochement vertical, les Grecs font le contraire. Les Français sifflent un acteur pour manifester leur mécontentement, les Améri-

(b)

Figure 10.4 Monopoly of Gentleness (vector drawing), 2020. Photograph reproduction. Boissonnas, Frédéric, and André Taponier. 1924. "European Kissing Her Child.” The Human Races, I3. Paris: Éditions Hachette.

years later-will be the subject of controversy. The famous Article 4 of the Law of 23 February 2005 reads: 'The school programs in particular acknowledge the positive role of the French presence overseas, especially in North Africa'. History will show - in an uncertain coincidence - that Azouz Begag, author of the book Le Gône du Chaâba, became Minister Delegate for the 
Promotion of Equal Opportunity between 2005 and 2007 during the heated debates around this article that shook the National Assembly. On 12 December 2005, Azouz Begag asked for the repeal of Article 4. In reply, the UMP (Union for a Popular Movement) deputy stated, 'If there hadn't been colonization, neither Mr. Léon Bertrand nor Mr. Azouz Begag would be ministers of the French Republic!' (Luca 2005). And he added, 'And don't tell me this law is going to set the suburbs on fire. You think in the suburbs that they take an interest in the laws?' (Thibaudat 2005). As a result, the small yellow notebook becomes a symbol, referring to the positive role of colonization.

I had made an appointment with our ophthalmologist for my mom and our eldest son. The doctor asked him, as she did each time she examined him, what level he was at in school. On learning that he had just passed his entrance exam for medicine - after a moment of surprise - she congratulated him and immediately added, 'Really, we live in a great country, we have a school that allows the kids from the lower classes to make it!' Basically I agreed with her on the school, but I felt a form of restraint when it came to feeling eternally indebted. She then examined my mother. 'What do you do during your day?' she asked her. My mother mumbled hesitantly, 'I do a little housework ... I watch TV ...' And I added, 'And you also take Arabic lessons.' Then the doctor turned toward me, asking, 'And why not French lessons?' (Figure 10.4)

Self-esteem, disparagement of the other, here this prevailing double-talk appears, of Europe with regard to Africa and its diaspora - deconstructed by Felwine Sarr.

The two discourses must be taken together, the "self branding": We are the best, we are the center of the world ... But the others, also, are underdeveloped, in the process of development ... We find terms that are always in the imagination of the civilizing mission.

(Sarr 2018)

\section{Notes}

1 D'un seuil, à l'autre, project produced with Martine Derain, 2004-2007. "Martine Derain," documentsdartistes.org. Accessed 5 March 2021. http://www.documentsdartistes.org/artistes/derain/reprol.html

2 Journal Officiel de la République Française. 1977. Débats parlementaires Assemblée Nationale - 1st session of 5 October, 5844. https://archives.assembleenationale.fr/5/cri/1977-1978-ordinaire1/004.pdf.

\section{References}

Baldwin, James. 1975. "Entretien de James Baldwin et Eric Laurent." Uploaded 19

December 2017. https://www.youtube.com/watch?v=sY2vkgSmnv8.

Baldwin, James. 2018. La prochaine fois le feu. Paris: Éditions Gallimard. 
Fanon, Frantz. 2014a. "Écoute homme blanc! De Richard Wright." Frantz FanonCuvres II, 524-29. Algiers: Éditions Hibr.

Fanon, Frantz. 2014b. "Les damnés de la terre.” Frantz Fanon-CEuvres, 419-681. Algiers: Éditions Hibr.

Luca, Lionnel. 2005. "Député au franc-parler." La Revue Parlementaire, No. 885.

Mbembe, Achille. 2016. Politique de l'inimitié. Paris: Éditions La Découverte.

Peck, Raoul. 2020. "J'étouffe." Le 1 Hebdo Hors-Série $N^{\circ} 301.17$ June 202. Accessed 9 March 2021. https://le1hebdo.fr/journal/jetouffe/301/article/j-touffe-3898.html

Phay, Soko. 2016. "Fictions mortifères et esthétisation de la mort." NAQD 33/34: 41-48.

Romana, Serge. 2019. “On n'est pas couché, 8 June 2019.” https://www.youtube.com/ watch?v=lqBRn7EPP1g.

Sarr, Felwine. 2016. Afrotopia. Paris: Éditions Philippe Rey.

Sarr, Felwine. 2018. "Faire le présent \# 6 - Geoffroy de Lagasnerie invite Felwine Sarr." Uploaded 19 June 2018. https://www.youtube.com/watch?v=aq_85aubLf0.

Taubira, Christiane. 2018. Préface to James Baldwin, La prochaine fois le feu. Paris: Éditions Gallimard.

Thibaudat, J.-P. 2005. "Citez-moi un manuel où l'on parle des pieds-noirs.” Libération, 30 November. https://www.liberation.fr/evenement/2005/11/30/citez-moi-unmanuel-ou-1-on-parle-des-pieds-noirs_540185. 